\title{
Metabolic Syndrome Among Patients with Rheumatoid Arthritis and the Correlation with Disease Activity
}

\begin{abstract}
CRISTINA GABRIELA ENE ${ }^{1 *}$, MIHAELA MITRO ${ }^{2 *}$, IONELA MIHAELA VLADU ${ }^{3 *}$, LUCRETIU RADU4, TIBERIU STEFANITA TENEA COJ AN ${ }^{5}$, ANCA MIHAELA PREDESCU6, MARIUS GABRIEL BUNESCU'

'University of Medicine and Pharmacy of Craiova, Pharmacology Department, Emergency Clinical Hospital of Craiova, 2-4 Petru Rares Str.,200349, Craiova, Romania

2University of Medicine and Pharmacy, Craiova Department of Otorhinolayngology, County Hospital Craiova, 2-4 Petru Rares Str., 200349,Craiova, Romania

${ }^{3} U$ niversity of Medicine and Pharmacy of Craiova, Department of Metabolism and Nutrition Diseases, Filantropia Clinical Hospital of Craiova, 1 Filantropiei Str., 200143, Craiova, Romania

${ }^{4}$ University of Medicine and Pharmacy of Craiova, Department of Hygiene, Filantropia Clinical Hospital of Craiova, 1 Filantropiei str., 200143, Craiova, Romania

5University of Medicine and Pharmacy of Craiova, Department of Surgery, CFR Hospital of Craiova, Stirbei-Voda Str., 200374,Craiova, Romania

'University of Medicine and Pharmacy of Craiova, Faculty of Dentistry Medicine, Histology Department, 2-4 Petru Rares Str., 200349, Craiova, Romania

ZUniversity of Medicine and Pharmacy of Craiova, Occupational Medicine Department, 2-4 Petru Rares Str., 200349, Craiova, Romania

Rheumatoid arthritis is a systemic inflamatory disease that affects primarily the synovial joints and it is associated with a progressive disability and a important socio-economic burden. [1] Although the main characteristic is the joint involvement, it is important to remember that RA is a disorder with systemic involvement mainly due to it's chronic inflamation. Patients with RA have a higher risk of cardio-vascular mortality that in general population. There are numerous studies thatsugest that inflamation plays a key"role in the develompent of aterosclerosis and heart disease, therefore a better understanding of the inflamatory response in RA may lead to better outcomes for patients with RA. Metabolic Syndrome is described as a congregate of major risk factors for cardiovascular diseases (CVD): Diabetes and raised fasting plasma glucose, abdominal obesity, high cholesterol and high blood presure[2]. The clustering of CVD risk factors that typifies the metabolic syndrome is now considered to be the driving force for a new CVD epidemic [3]. The conducted study aims to assess and evaluate the presence of metabolic syndrome (MetS) in RA patients. 120 patients with RA ( 89 women and 31 men) and 120 ( 85 women and 35 men) patients without RA were included in the study. The prevalence of MetS in RA patients was 39.16\% and 22.5\% for the control group. RA patients with MetS had significantly higher disease activity score of 28 joints index (DAS28-ESR) than patients without MetS ( $3.70 \pm 0.644$ vs. $3.35 \pm 0.725 ; p=0.006)$.
\end{abstract}

Keywords: Rheumatoid arthritis, Metabolic Syndrome, inflamation, disease activity, cardiovascular risk

Rheumatoid arthritis (RA) is an autoimmune condition characterized by a systemic aberrant inflammatory response whose main feature is joint damage especially to the small joints of the hands and feet.

The character of systemic disease is demonstrated by multiple extraarticular affections and numerous studies have demonstrated that approximately between $50 \%$ and $80 \%$ of RA patients present extraarticular manifestations during the course of the disease and their presence is associated with a more aggressive disease status.

Patients with RA have a higher risk of cardio-vascular mortality that in general population. There are numerous studies sugesting that inflamation plays a key role in the develompent of atherosclerosis and heart disease, therefore a better understanding of the inflamatory response in RA may lead to better outcomes for patients with RA.

Metabolic syndrome is a group of major risk factors for type 2 diabetes and cardiovascular diseases (CVD), including insulin resistance, abdominal obesity, dyslipidemia, hypertension, and impaired fasting glucose, incorporated into a single disease group [4].

\section{Experimental part \\ Aim of the study}

The present study aims to evaluate the prevalence of MetS and it's components in patients with RA. Correlation between disease activity, inflamation response in RA and the presence of MetS among patients with RA could identify subjects at an aditional higher risk of cardio-vascular events in order to provide a better outcome in management of patients with RA.

\section{Material and methods}

The conducted study was a prospective longitudinal study and included 120 patients previously diagnosed with RA undergoing different type of Disease-modifying antirheumatic drugs (DMARDs) in the Medical Clinic of the Railway Clinical Hospital of Craiova from J anuary 2017 to January 2019 and a control group consisting of 120 patients comparable to age and sex without RA that were hospitalized in the same clinical service.

For all the patients included in the study, RA diagnosis was according to the 2010 American College of 
Table 1

INTERNATIONAL DIABETES FEDERATION - NATIONAL CHOLESTEROL EDUCATION PROGRAMME ADULT TREATMENT PANEL III (IDF - NCEP ATP III) GUIDELINES FOR METABOLIC SYNDROME

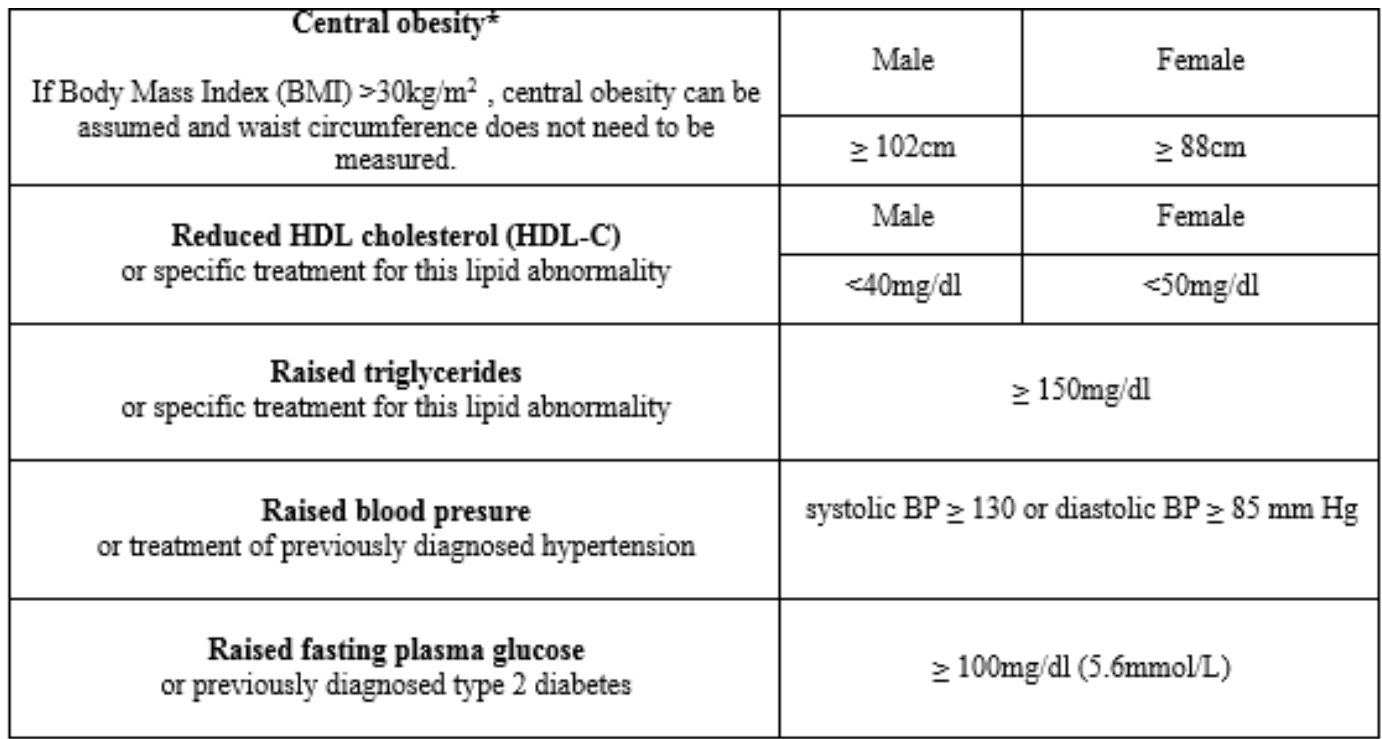

Rheumatology (ACR)/ European League Against Rheumatism (EULAR) classification criteria [5].

The assessment of MetS was made for all the patients included in the study. MetS was defined according to International Diabetic Federation - National Cholesterol Education Programme Adult Treatment Panel III (IDF NCEP ATP III) guidelines where a minimum of 3 criteria must be fulfilled for the diagnosis of Metabolic Syndrome (table 1).

For all the patients included in this study, demographic data regarding sex and age were collected, blood preasure (systolic and diastolic) was measured each, day during their hospitalisation and anthropometric measurements were taken (weight, height, waist circumference). Blood samples were collected from which we tested total cholesterol, high density lipoprotein cholesterol (HDL-C), triglycerides, serum glucose concentration.

Additionally, for the patients with RA, the erythrocyte sedimentation rate (ESR), rheumatoid factor (RF), Creactive protein (CRP), and anticyclic citrullinated peptide (anti-CCP) were measured and the assessment of disease activity was made using the Disease activity score of 28 joints (DAS28-ESR) (table 2).

\section{Table 2}

DISEASE ACTIVITY CLASSIFICATION ACCORDING TO DAS28-ESR

\begin{tabular}{|c|c|}
\hline \multicolumn{2}{|c|}{$\begin{array}{c}\text { Disease activity score of 28 joints with ESR } \\
\text { (DAS28-ESR) }\end{array}$} \\
\hline Disease activity & DAS28 ESR \\
\hline Remission & $<2.6$ \\
\hline Low disease activity & $<3.2$ \\
\hline Moderate disease activity & $<5.1$ \\
\hline High disease activity & $>5.1$ \\
\hline
\end{tabular}

The study was conducted according to the Declaration of Helsinki and local regulations. Ethical approval for the study was obtained from the local ethics commitee and also, patients in both groups signed an informed consent.

Statiscal analysis were made using IBM Statistical Package for Social Science (IBM SPSS) V 20.0 where a $p$ value $<0.05$ was considered significant.

\section{Results and discusions}

The analisys of the demographic data showed no statistically significant differences between the studied groups. Among the RA patients $89(74.16 \%)$ were women and $31(25.83 \%)$ were men, while in the control group 85 were women $(70.83 \%)$ and $35(29.16 \%)$ were men (fig. 1). Patients in RA group were aged between 26 and 72 years old with a mean age of $52.77 \pm 10.40$, while in the control group, patients were aged between 23 and 75 years old with a mean age of $53.55 \pm 11.49(p=0.585)$ (table 3$)$.

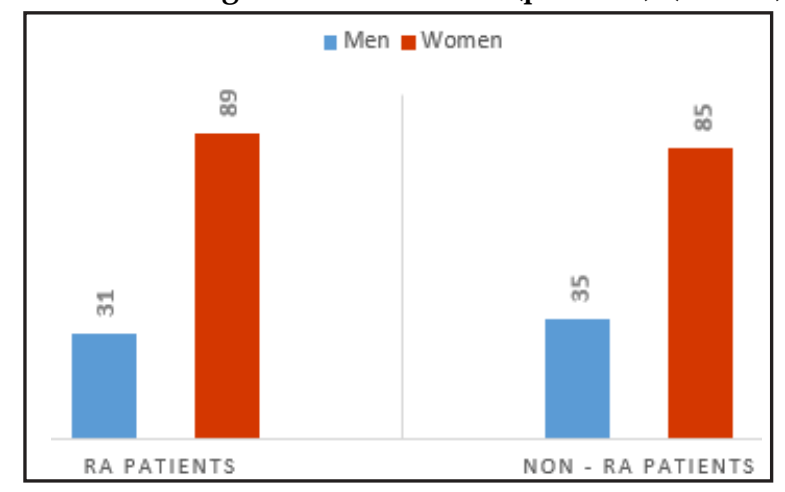

Fig. 1. Sex distribution among both studied groups

Regarding the prevalence of MetS in both groups, we found that this was higher in the RA group comparing to the control group ( $p=0.005$ ) (fig. 2). Thus, in the presented study we found 74 patients with MetS (30.83\% from all the patients enrolled in the study. Among the group of patients with RA, 47 patients (39.16\%) had MetS while, in the control group, only 27 patients fulfilled the criteria for MetS (22.5\%) (table 4).

Regarding the metabolic syndrome components as defined in table1, the conducted study showed that central obesity was found in 45 RA patients (37.5\%) vs. $22(18.33 \%)$ patients from the control group $(p=0.001)$. Regarding low levels of HDL-C, we found no significant differences between both groups $(p=0.112)$, while high triglyceride levels were found in 65 (54.16\%) RA patients vs. 36 (30\%) Non-RA patients. High blood presure was accounted in 48 (38.33\%) RA patients and in 29 (24.16\%) patients from control group. Regarding high glucose levels, 30 patients had RA while 17 where Non-RA patients $(p=0.035)$ (table 5). 


\begin{tabular}{|c|c|c|c|c|c|}
\hline \multicolumn{2}{|r|}{ Variables } & \multicolumn{2}{|c|}{ RA patients $(n=120)$} & \multicolumn{2}{|c|}{ Non- RA patients $(n=120)$} \\
\hline \multirow{2}{*}{ Sex } & Women & 89 & $74.16 \%$ & 85 & $70.83 \%$ \\
\hline & Men & 31 & $25.83 \%$ & 35 & $29.16 \%$ \\
\hline & & \multicolumn{4}{|c|}{$P=0.565$} \\
\hline \multirow{2}{*}{ Age } & Mean age & & 77 & \multicolumn{2}{|c|}{53.55} \\
\hline & Std. Deviation & \multicolumn{2}{|c|}{ \pm 10.40} & \multicolumn{2}{|c|}{ \pm 11.49} \\
\hline & & \multicolumn{4}{|c|}{$P=0.585$} \\
\hline
\end{tabular}

Table 3

DEMOGRAPHIC ASSESSMENT OF THE PATIENTS INCLUDED IN THE STUDY

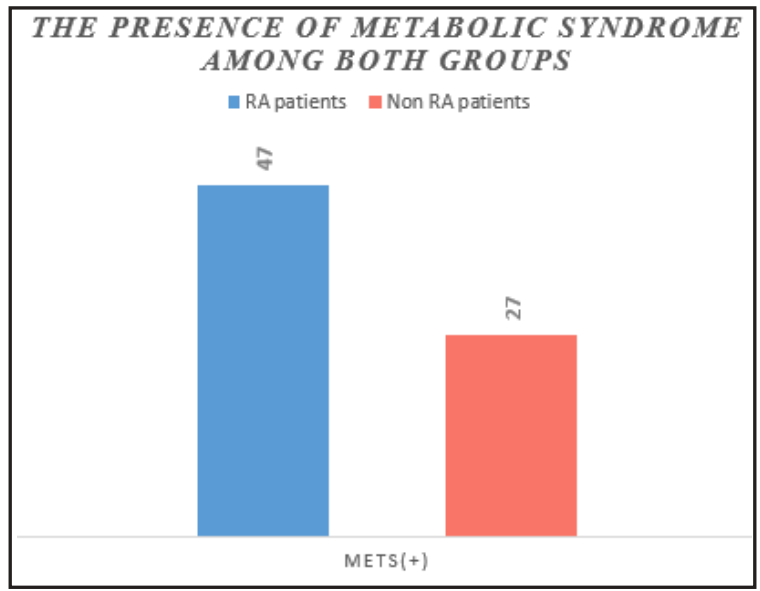

Fig. 2. The presence of MetS among both groups

Fig. 2. The presence of MetS among both groups

\begin{tabular}{|c|c|c|c|c|}
\hline & \multicolumn{2}{|c|}{ RA patiens (n=120) } & Non-RA patients (n=120) \\
\hline & Women (n=89) & Men (n=31) & Women (n=85) & Men (n=35) \\
\hline MetS $(+)$ & $33(37.07 \%)$ & $14(45.16 \%)$ & $18(21.17 \%)$ & $9(25.71 \%)$ \\
\hline MetS $(-)$ & $56(62.92 \%)$ & $17(54.83 \%)$ & $67(78.82 \%)$ & $26(74.28 \%)$ \\
\hline & \multicolumn{4}{|c|}{$P=0.005$} \\
\hline
\end{tabular}

Table 4

METABOLIC SYNDROME IN PATIENTS AMONG BOTH GROUPS

\begin{tabular}{|l|c|c|c|}
\hline $\begin{array}{c}\text { IDF - NCEP ATP III guidelines for } \\
\text { MetS }\end{array}$ & RA patients & Non-RA patients & P value \\
\hline Central obesity & $45(37.5 \%)$ & $22(18.33 \%)$ & $P=0.001$ \\
\hline Low HDL-C & $70(58.33 \%)$ & $58(48.33 \%)$ & $P=0.112$ \\
\hline High trglycerides levels & $65(54.16 \%)$ & $36(30 \%)$ & $P=0.0001$ \\
\hline Raised blood presure & $48(38.33 \%)$ & $29(24.16 \%)$ & $P=0.008$ \\
\hline Raised fasting plasma glucose & $30(25 \%)$ & $17(14.16 \%)$ & $P=0.035$ \\
\hline
\end{tabular}

Table 5

METABOLIC SYNDROME COMPONENTS AMONG BOTH GROUPS

\begin{tabular}{|c|c|c|c|c|c|}
\hline & Patients & \multicolumn{4}{|c|}{ DAS28-ESR } \\
\cline { 3 - 6 } & & Min & Max & Mean & Std. devaition \\
\hline RA patients with MetS & $\begin{array}{c}47 \\
(39.16 \%)\end{array}$ & 2.5 & 5.4 & 3.70 & \pm 0.644 \\
& $\begin{array}{c}73 \\
\text { RA patients without MetS }\end{array}$ & 2.5 & 5.1 & 3.35 & \pm 0.725 \\
& $(60.83 \%)$ & & & & \\
\hline & \multicolumn{5}{|c|}{$P=0.006$} \\
\hline
\end{tabular}

CORRELATION BETWEEN THE PRESENCE OF METS IN RA PATIENTS AND DISEASE ACTIVITY
Disease activity was also evaluated in patients with RA. Our study showed thatDAS28-ESR was significantly higher in RA patients with MetS ( $3.70 \pm 0.644)$ than in RA patients without MetS (3.35 \pm 0.725 ) (table 6).

The cardiovascular risk quantitation is a golden desideratum for clinical management [6-8] allowing a better and more accurate medical care for the patients.

Patients with RA are known to have an increased risk of cardiovascular events early in life [9] than in general populations. Meune $C$ et al on a meta-analysis over 50 years showed that RA is associated with a increased morbidity 
adipose tissue. Obesity is known as one of the most important risk factor for cardiovascular disease.[12-15] The prevalence of obesity has increased by $10-40 \%$ over the past ten years with an estimated number of 302.1 million adult with obesity worldwide ( $8.2 \%$ of the world's population) [16]. Many studies sugest that adipose tissue represents a source of proinflamatory cytokines - like interleukin 6 (IL-6) or tumour necrosis factor $\alpha$ (TNF $\alpha$ ). [17-19] TNF $\alpha$ interferes with insulin signaling inducing insulin resistance which Eckel $\mathrm{RH}$ et al consider to be the basic metabolic disturbance of MetS [20-23].

\section{Conclusions}

The presented study showed a significant higher prevalence of metabolic syndrome in patients with rheumatoid arthritis coparable with control group.

Comparing the prevalence of metabolic syndrome components in both group, we observed that each component of metabolic syndrome had a significantly higher prevalence among patients with rheumatoid arthritis comparable to control group.

A correlation between disease activity of rheumatoid arthritis and metabolic syndrome showed that patients with both rheumatoid arthritis and metabolic syndrome had higher values of DAS28-ESR index comparable with patients with rheumatoid arthritis without metabolic syndrome.

\section{References}

1.QIANG GUO, YUXIANG WANG, DAN XU, JOHANNES NOSSENT, NATHAN J. PAVLOS AND JIAKE XU (2018). Rheumatoid arthritis: Pathological mechanisms and modern pharmacologic therapies. Bone Research. 6. 10.1038/s41413-018-0016-9

2.*** Expert Panel on Detection, Evaluation, and Treatment of High Blood Cholesterol In Adults (Adult Treatment Panel III) Executive summary of the third report of The National Cholesterol Education Program (NCEP). JAMA 20012852486-2497

3.SIDIROPOULOS PI, KARVOUNARIS SA, BOUMPAS DT, Metabolic syndrome in rheumatic diseases: epidemiology, pathophysiology, and clinical implications, Arthritis Res Ther. 2008;10(3):207 Epub 2008 May 8.

4.ALETAHA D, NEOGI T, SILMAN AJ, FUNOVITS J, FELSON DT, BINGHAM CO 3RD, ET AL. 2010 Rheumatoid arthritis classification criteria: an American College of Rheumatology/European League Against Rheumatism collaborative initiative. Arthritis Rheum . 2010;62(9):256981

5.VLADU,M.,. RADU, L., GIRGAVU, S.R.,BALEANU, V., CLENCIU, D., ENE,C.G., SOCEA,B.,MAZEN, E., CRISTEA, O.M.,. MOTA,M.,. TENEA COJAN,T.S.,An Easy Way to Detect Cardiovascular Risk, Rev. Chim..(Bucharest), 69, no.11, 2018,p. 4229-4232

6.PUIU I., DAN A.O., TARTEA E.A., ROGOVEANU O.C., BICA E.A., DINESCU S.N., VASILE R.C., DINESCU V.C., ROMANESCU F.M., TUDORASCU D.R. Assessing Factors that influence the Level of Glycated Hemoglobin in Children and Adolescents with Type 1 Diabetes. Rev. Chim. (Bucharest), 69, no. 11, 2018, p.4233-4236.

7.V. CALBOREAN, I. UDRISTOIU, A. D. DOCEA, M. C. HODOROG,S. N. DINESCU, O. CRICIOTOIU, D. STANCA, A. MITA, D. V. DAVITOIU, V. D. BALEANU, F. M. ROMANESCU, M. BICA, C. S. MIREA ,V. C. DINESCU. Evaluation of Echocardigraphic Parameters in Patients with Rhythm Disorders Associated with Chronic Hepatic Disease. Rev Chim (Bucharest) 70, no. 2, 2019, p. 659-662.
8.CALBOREAN, V., CIOBANU, D., MIREA, S.C., GALCEAVA, O.,GHEORMAN, V., PADUREANU, V., FORTOFOIU, C.M., FORTOFOIU,M., MITA, A., DINESCU, S.N., MISCOCI, S.A., DINESCU, V.C., Benefit of Cardiac Resynchronization Therapy in Patients with Heart Failure. Rev. Chim. (Bucharest), 69, no. 9, 2018, p.2744-2748. 9.AVINA-ZUBIETA JA, CHOI HK, SADATSAFAVI M, ET AL. Risk of cardiovascularmortality in patients with rheumatoid arthritis: a metaanalysis of observational studies.Arthritis Rheum 2008;59(12):1690-1697 10.MEUNE C, TOUZE E, TRINQUART L, ALLANORE Y. Trends in cardiovascular mortality in patients with rheumatoid arthritis over 50 years: a systematic review and meta-analysis of cohort studies. Rheumatol2009; 48(10): 1309-13

11.I.E. DUMITRESCU , M. DUNITRESCU, L. STANESCU，D. PREDETEANU , RHEUMATOID ARTHRITIS -AN ENEMY OF THE HEART, ROMANIAN J OURNAL OF CARDIOLOGY, VOL. 27, No. 4, 2017, 528-532 12.CALBOREAN, V., GHEORMAN, V.,CONSTANTIN, C. ISTRATOAIE, O.Venous Thromboembolism Secondary to Adult-Onset Still's Disease: a Case Report, Journal of Cardiovascular Emergencies, 2018, 4, nr.2,p.101-105.

13.CALBOREAN, V., GHEORMAN, V., DINESCU, S.N., STANCA, D., GALCEAVA,O.,. FORTOFOIU, M.,MITA, A.., MIHAILOVICI, A.R.,. MISCOCI, S.A.,BALEANU,D.,. DINESCU,V.C., Arrhythmia Risk in Patients with Chronic Hepatic Disease. Rev. Chim (Bucharest) 69, no. 11, 2018, p. 4237-4240.

14.DINESCU, V..C., PUIU, I., DINESCU, S.N., TUDORASCU, D.N., BICA, E.C., VASILE, R.C., BUNESCU, M.G., ROMANESCU, F.M., CIOATERA, N., ROTARU, L.T., MUSTAFA, E.R., FLORESCU, F., Early Predictive Biochemical Electrocardiographic and Echocardiographic Markers for Cardiac Damage in Patients with Pulmonic Silicosis. Rev Chim (Bucharest), 70, no.1, 2019, p.63-68.

15.CALBOREAN,V., GHEORMAN,V., AL NAMAT, R., CAZACU,I. M., VARJU,P., GEDE, N., STREBA,T.C., VERE, C.C., GHEONEA,D.I., GHEORMAN, V., LUNGULESCU, C., LUNGULESCU, C., V. The Association Between Stress Level and Laboratory Parameters, Sex, Age and Stage Disease in Patients with Digestive and Bronchopulmonary Neoplasms, Rev Chim (Bucharest), 68, no 12, 2017, p.30123014.

16.SOCEA, B., RADU, L.,CLENCIU, D.,TENEA COJAN, T.S., BALEANU,V., ENE, C.G., GIRGAVU,S.R., VLADU,I.M., The Utility of Visceral Adiposity Index in Prediction of Metabolic Syndrome and Hypercholesterolemia, Rev.Chim.,(Bucharest) 69,no. 11, 2018, p. 3112-3114 17.TRAYHURN P, WOOD I S. Adipokines: inflammation and the pleiotropic role of white adipose tissue. Br J Nutr 200492347-355 18.L. RADU, M. CARSOTE, A. A. GHEORGHISAN GALATEANU, S.A. PREDA, V. CALBOREAN, R. STANESCU, V. GHEORMAN, D. M. ALBULESCU, Blood Parathyrin and Mineral Metabolism Dynamics - A clinical analyze, Rev. Chim.(Bucharest) 69, no. 10, 2018, p. 2754-2758 19.L. RADU, M. CARSOTE, A.M. PREDESCU, T.ST.TENEA-COJ AN, B. SOCEA, V.D. BALEANU, M. POPESCU, N.IONOVICI, D.M. ALBULESCU - Biochemical parameters in patients using teriparatide 20.VILCEA I.D., VASILE I. TOMESCU P. ET AL, Loco-regional advanced colorectal cancer: diagnostic and therapeutic features, CHIRURGIA vol 103, Issue 2 (2008) pg189-194;

21.VASILE I., MIREA C., VILCEA I.D. ET ALL Esophago-digestive anastomosis dehiscence Chirurgia, vol 104, No. 3 (May-lun 2009), pg 281-286

22.TENEA COJAN T.S., VIDRIGHIN C.D., CIOBANU M. ET AL : Breastconserving surgery in breast cancer, Chirurgia, Vol 107, Issue 5 (2012), pg. 616-625

23.ECKEL R H, GRUNDY S M, ZIMMET P Z. The metabolic syndrome. Lancet 20053651415-1428.

Manuscript received: 30.10 .2018 